J. Dairy Sci. 98:7893-7898

http://dx.doi.org/10.3168/jds.2015-9415

(C) American Dairy Science Association ${ }^{\circledR}, 2015$.

\title{
Short communication: Subtyping of Staphylococcus haemolyticus isolates from milk and corresponding teat apices to verify the potential teat-skin origin of intramammary infections in dairy cows
}

\author{
Frédéric Leroy, ${ }^{* 1}$ Els Van Coillie,$\dagger^{1}$ Gorik Braem, ${ }^{*}$ Veerle Piessens, $\dagger$ Bert Verbist, $\dagger$ Luc De Vuyst, ${ }^{*}$ \\ and Sarne De Vliegher $\ddagger^{2}$ \\ ${ }^{*}$ Research Group of Industrial Microbiology and Food Biotechnology (IMDO), Faculty of Sciences and Bioengineering Sciences, \\ Vrije Universiteit Brussel, Pleinlaan 2, B-1050 Brussels, Belgium \\ †Institute for Agricultural and Fisheries Research (ILVO), Brusselsesteenweg 370, B-9090 Melle, Belgium \\ $\ddagger$ M-team and Mastitis and Milk Quality Research Unit, Department of Reproduction, Obstetrics and Herd Health, Faculty of Veterinary Medicine, \\ Ghent University, Salisburylaan 133, B-9820 Merelbeke, Belgium
}

\begin{abstract}
Coagulase-negative staphylococci (CNS) are a major cause of intramammary infections (IMI) in dairy cows and they colonize the teat skin. Staphylococcus haemolyticus, one of the more common CNS, has been identified as a highly versatile opportunistic species. The aim of the present study was to gain better insight into the adaptation of $S$. haemolyticus subtypes to the udder ecosystem with respect to IMI development. During a longitudinal observational study conducted over 13 mo on 6 Flemish dairy herds, S. haemolyticus isolates were recovered from milk and teat apices. A total of 44 S. haemolyticus isolates originating from milk (24 isolates) and teat apices (20 isolates) of 6 selected udder quarters were singled out and analyzed using a combined methodology of (GTG) $)_{5}-\mathrm{PCR}$ and amplified fragment length polymorphism (AFLP) fingerprinting to determine intraspecies differences. Combining both fingerprinting methods, $4 \mathrm{~S}$. haemolyticus subtypes were obtained (I to IV). Subtypes I, II, and IV were recovered from both milk and teat apex samples and were found to be associated with persisting IMI. Subtype III, not apparently related to IMI, was isolated solely from teat apices and not from milk. In general, S. haemolyticus subtypes found in milk from infected quarters could be recovered from the corresponding teat apices, although the latter could be colonized with up to 3 different subtypes. Comparing subtypes from milk and teat apices indicates that the IMI-causing agent likely originates from the teat skin.
\end{abstract}

Received February 3, 2015.

Accepted June 15, 2015.

${ }^{1}$ These authors contributed equally to the research.

${ }^{2}$ Corresponding author: Sarne.Devliegher@UGent.be
Key words: amplified fragment length polymorphism (AFLP) fingerprinting, (GTG) $)_{5}$ PCR fingerprinting, Staphylococcus haemolyticus, teat apex, bovine mastitis

\section{Short Communication}

Coagulase-negative staphylococci have mostly been described as part of the normal skin microbiota of cows but have also been linked to mild cases of clinical and subclinical IMI (Vanderhaeghen et al., 2014). Apparent contradictions have been noticed regarding the effect on udder health of CNS at the species level. For instance, Staphylococcus chromogenes can be associated with clinical mastitis (Zadoks and Watts, 2009) but also exerts protective properties (De Vliegher et al., 2003; Braem et al., 2014). These inconsistencies could indicate strain dependence of the pathogenic versus protective potential of CNS. Although CNS are abundantly present on the teat apices and in the immediate environment of cows, differences exist between species in their adaptation to different niches (De Vliegher et al., 2003; Taponen et al., 2008; Piessens et al., 2011; Braem et al., 2013; De Visscher et al., 2014). Previously, S. chromogenes, Staphylococcus epidermidis, Staphylococcus haemolyticus, Staphylococcus simulans, and Staphylococcus xylosus have been identified as the CNS species most likely to cause IMI (Piessens et al., 2011; Vanderhaeghen et al., 2014). Staphylococcus haemolyticus has been isolated regularly from both milk, when linked to IMI (Fry et al., 2014), and environmental samples (Piessens et al., 2011), and is frequently present on teat apices (Braem et al., 2013). As well, high genetic heterogeneity among $S$. haemolyticus isolates has been detected through genomic DNA fingerprinting (Piessens et al., 2012). Overall, this information suggests that $S$. haemolyticus is a highly versatile opportunist that can adapt to intramammary as well as to skin and environmental conditions. Although accurate 
identification of the different Staphylococcus species has assisted in identifying differences in epidemiology, ecology, virulence, resistance patterns, and effect on udder health among species, strain differences among species potentially hamper proper interpretation of the findings. Therefore, S. haemolyticus isolates from milk and teat apices of selected quarters from dairy cows were compared to establish intraspecies variability using 2 whole-genome typing methods: (GTG) $)_{5}$ PCR and amplified fragment length polymorphism (AFLP) fingerprinting. By determining whether S. haemolyticus isolates from teat apices and from milk samples of specific quarters belonged to the same subtype, we aimed to gain better insight into the origin of IMI caused by S. haemolyticus.

Six Flemish dairy herds (A to F) were visited once a month over a course of 13 mo (1-13), during which time quarter milk samples and teat apex samples of the same 10 cows per farm were taken to determine the CNS species and subspecies diversity in these niches and their persistence, as described in previous studies (Piessens et al., 2011; Braem et al., 2013). Herds were well managed, and herd and management characteristics reflected the general situation in Flemish dairy herds (Piessens et al., 2011). Teat apices were sampled using a sterile swab, covering the area $( \pm 0.5$ $\mathrm{cm}^{2}$ ) around the teat orifice. After sampling of the teat apex and removing some streams of milk, quarter milk samples were aseptically taken according to standard procedures (Hogan et al., 1999). Bacterial cultivation of staphylococci from the teat apical samples was performed through plating on mannitol salt agar (VWR International, Darmstadt, Germany). Approximately $10 \%$ of all colonies were isolated, encompassing every distinctly different phenotype present. Bacteriological culturing of the milk samples and isolation of CNS was performed in the laboratory of the Milk Control Centre Flanders (MCC, Lier, Belgium) as described previously (Piessens et al., 2011). The isolated colonies were purified through successive streaking. Overnight broth cultures in brain-heart infusion agar (Oxoid, Basingstoke, $\mathrm{UK}$ ) were stored at $-80^{\circ} \mathrm{C}$ in brain-heart infusion medium containing $20 \%$ ( $\mathrm{vol} / \mathrm{vol}$ ) glycerol. Diagnosis of CNS-linked IMI of quarters was done as described in detail by Piessens et al. (2011).

Staphylococcus haemolyticus was among the most frequently isolated CNS species and was isolated from $1.4 \%(37 / 2,580)$ of quarter milk samples (Piessens et al., 2011) and $17.4 \%(450 / 2,580)$ of teat apex swabs (unpublished results). From 6 quarters of 3 cows (coded as B1, D1, and D8) from 2 herds (B and D), S. haemolyticus was simultaneously isolated at least once from quarter milk samples and from teat apex skin. These quarters were selected for further analysis and all $S$. haemolyticus isolates from the corresponding quarters and teat apices obtained during the longitudinal study were used for the current study. Hence, 24 isolates originating from milk and 20 isolates originating from the teat apex were compared by molecular typing.

Subtyping of the strains was done by using a combination of $(\mathrm{GTG})_{5} \mathrm{PCR}$ and AFLP fingerprinting. For $(\mathrm{GTG})_{5}$-PCR fingerprinting, DNA extraction, subsequent PCR amplification with the single oligonucleotide (GTG) $)_{5}$ primer (5'-GTGGTGGTGGTGGTG-3'), and gel electrophoresis were performed as detailed in Braem et al. (2011). For AFLP analysis, genomic DNA extraction, DNA restriction with MseI and HindIII, and generation of AFLP fingerprints was done as described previously (Piessens et al., 2010). Fingerprints were analyzed by using BioNumerics 5.10 (Applied Maths NV, Sint-Martens-Latem, Belgium), and similarities were calculated via Pearson correlation followed by UPGMA (unweighted pair group method with arithmetic mean) clustering. The AFLP and (GTG) ${ }_{5}-\mathrm{PCR}$ fingerprinting patterns of all isolates were analyzed with an equal internal weight (1:1) to compose a combined fingerprint. Each combined fingerprint type was assigned a roman numeral to identify a certain subtype.

Combined (GTG) $)_{5}$ PCR and AFLP fingerprinting subdivided the $S$. haemolyticus isolates into 4 subtypes (I to IV; Figure 1). The largest subtype I $(\mathrm{n}=19)$ consisted of isolates from both milk $(\mathrm{n}=12)$ and teat apices $(\mathrm{n}=7)$ and the combined fingerprint clustered together with a similarity of $67.1 \%$. Groups II [n $=12(9$ from milk and 3 from teat apices); similarity of 73.6\%] and IV $[\mathrm{n}=6$ (3 from milk and 3 from teat apices); similarity of $63.8 \%$ ] also consisted of a mixture of both milk and teat apex isolates, whereas group III $(n=7$; similarity of $87.5 \%$ ) contained only isolates originating from teat apices. These different subtypes strengthen previous observations on genetic heterogeneity among S. haemolyticus isolates from milk and the environment of dairy farms (Piessens et al., 2012). Wide diversity has been previously described for nosocomial isolates of this species, using pulsed-field gel electrophoresis, random amplification of polymorphic DNA, and repetitive element-PCR fingerprinting methods (Degener et al., 1994; Noordhoek et al., 1997; Takeuchi et al., 2005, Zong et al., 2011).

An overview of the distribution of the 44 isolates among quarters within cows over time is given in Table 1. Subtypes I, II, and IV were recovered from both milk samples and teat apices and caused chronic IMI, whereas subtype III was isolated only from teat apices.

Ten of the $S$. haemolyticus isolates originated from the left hind quarter of cow B1 (B1-2) and belonged 


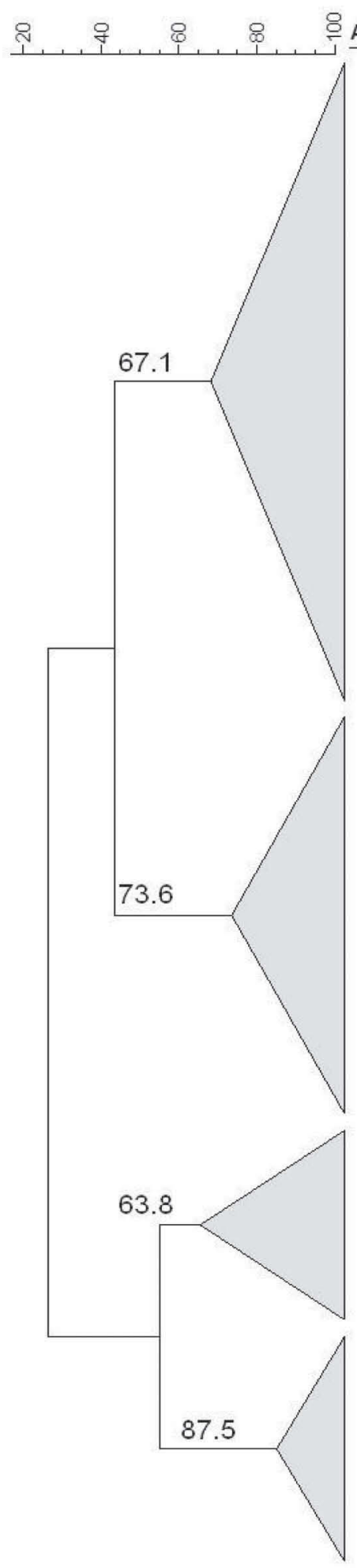

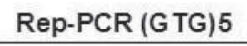
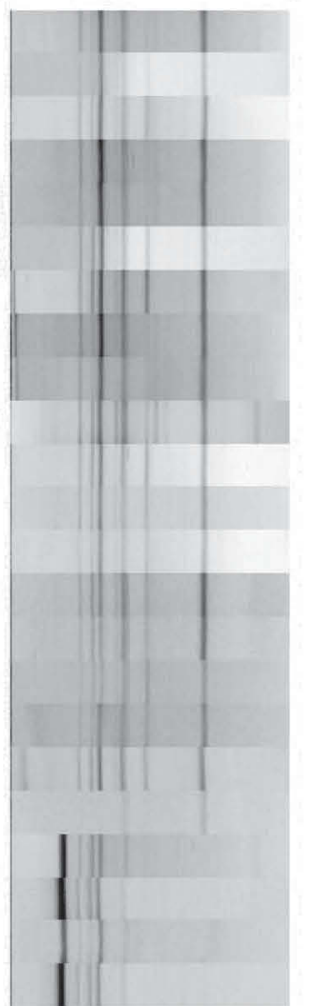

MAS 534

MAS 532

MAS 446

MAS 448

MAS 540

MAS 933

MAS 441

MAS 518

MAS 1272

MAS 658

MAS 682

MAS 681

MAS 1231

MAS 1262

MAS 1225

MAS 1260

MAS 1263

MAS 519

MAS 538

MAS 936

MAS 669

MAS 686

MAS 685

MAS 670

MAS 819

MAS 820

MAS 1251

MAS 1252

MAS 1240

MAS 388

MAS 445

MAS 683

MAS 1234

MAS 1256

MAS 1238 TA

MAS 1235 TA

MAS 1247 TA

MAS 1249 TA

MAS 1264 TA

MAS 1226 TA

MAS 1261 TA

MAS 1228 TA

$T A$

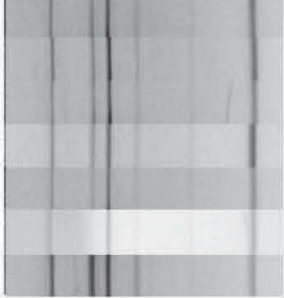

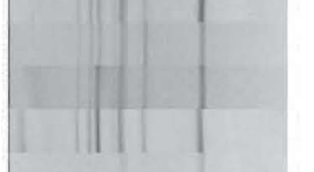

MAS 1233

Cow- Month Subtype quarter

Milk* D1-3

D1-3 1 ।

Milk

D1-4

Milk D1-3

Milk*

D1-3

D1-4

Milk*

B1-2

B1-2

Milk*

B1-2

B1-2

B1-2

B1-2

D1-3

D1-4

B1-2

D1-3

B1-2

D8-2

D1-3

D1-3

D8-2

D8-2

D8-2

Milk* D8-3 5 II

Milk* D8-2 6 II

Milk* D8-3 6 II

Milk* D8-2 5 II

Milk* D8-3 7 II

Milk* D8-2 7 II

D8-2 5 II

D8-3 5 II

$\begin{array}{llll}\text { TA } & \text { D1-4 } & 4 & \text { II } \\ \text { Milk* } & \text { D1-1 } & 1 & \text { IV }\end{array}$

Milk* D1-1 2 IV

Milk D1-1 6 IV

$\begin{array}{lll}\text { TA D } & \text { D -3 IV }\end{array}$

A D1-1 6 IV

D1-4 4 IV

D1-1 4 III

D8-2 4 III

D8-3 4 III

D1-4 6 III

B1-2 5 III

D1-3 6 III

B1-2 7 III

Figure 1. Dendrogram generated with combined $\mathrm{GTG}_{5} \mathrm{PCR}$ and amplified fragment length polymorphism (AFLP) fingerprinting of genomic DNA from Staphylococcus haemolyticus isolates recovered from milk samples and teat apices (TA) of 6 udder quarters $(1=$ left front; $2=$ left hind; 3 = right hind; and $4=$ right front quarter) of 3 dairy cows from 2 herds over time. ${ }^{*}$ Isolates are from CNS IMI. 
Table 1. Distribution of Staphylococcus haemolyticus subtypes (I to IV) recovered from milk samples and teat apices (TA) of 6 udder quarters of 3 dairy cows from 2 herds over time ${ }^{1}$

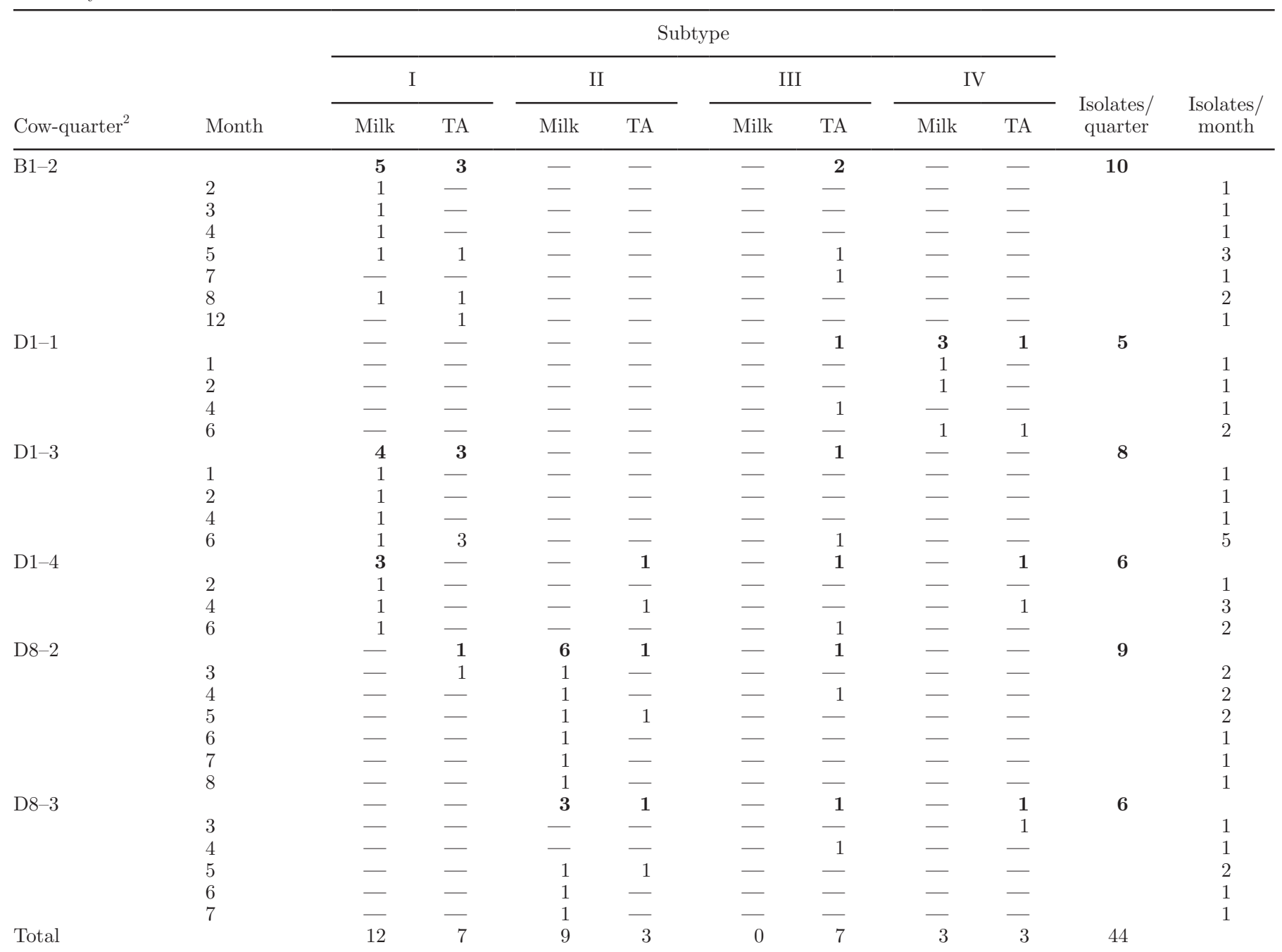

${ }^{1}$ Subtyping of the isolates was based on a combined methodology of (GTG) $)_{5}$-PCR fingerprinting and amplified fragment length polymorphism (AFLP) fingerprinting to reveal intraspecies differences. Total number of isolates of a specific subtype recovered from a cow-quarter and total number of isolates/quarter are indicated in bold.

${ }^{2}$ Cows: B1, D1, and D8; Quarters: $1=$ left front; $2=$ left hind; $3=$ right hind; and $4=$ right front.

to subtypes I and III. The corresponding teat apex was colonized with both subtypes I and III, but only subtype I was recovered from milk. The latter subtype was repeatedly isolated from milk, indicating the presence of chronic IMI, and at 2 samplings, the same subtype (I) was recovered from both the milk and teat apex samples (isolates MAS 658 and MAS 1225 in mo 5, and isolates MAS 933 and MAS 1231 in mo 8).

In the case of cow D1, $19 \mathrm{~S}$. haemolyticus isolates were recovered from milk and teat apices. The left front quarter (D1-1) had 5 S. haemolyticus isolates that belonged to 2 subtypes. At the sixth sampling, subtype IV was recovered from both the milk and teat apex of the left front quarter (isolates MAS 683 and MAS
1256) as was true for subtype I from the right hind quarter (isolates MAS 682 and MAS 1260). Eight isolates originated from the right hind quarter of the same cow (D1-3), of which 7 belonged to subtype I. Of these, 4 were recovered from milk and 3 from the teat apex. From the right front quarter of the same cow (D1-4), 6 isolates were recovered, belonging to 4 different subtypes. None of the types was recovered from both milk and the teat apex.

For cow D8, S. haemolyticus $(\mathrm{n}=15)$ was isolated from milk and the teat apices of 2 quarters. The left hind quarter (D8-2) harbored 9 S. haemolyticus isolates belonging to 3 subtypes, but only subtype II was recovered both from milk and teat apices. The latter 
subtype was repeatedly isolated from milk, indicating the presence of chronic IMI, but at only one sampling was it found on both teat apices and in milk (isolates MAS 0670 and MAS 1251). Six isolates belonging to 3 subtypes (II, III, and IV) originated from the right hind quarter of this cow (D8-3). Only type II was isolated from both milk and teat apices at the same sampling (isolates MAS 669 and MAS 1252).

Overall, the obtained results indicate that $S$. haemolyticus persist for a long time in milk compared with persistence on teat apices. In our previous studies, $S$. haemolyticus was found to persist for only a short time in the udder compared with other species (Supré et al., 2011) and was one of the most frequently detected species on teat apices (De Visscher et al., 2014). However, in the latter studies, CNS isolates were not subtyped so different subtypes or strains might have been detected on consecutive samplings of a specific quarter.

The results reveal simultaneous isolation of the same S. haemolyticus subtype from milk and teat apices. This was the case in quarters without and with chronic IMI. This indicates that strains that cause IMI do not necessarily differ from those that belong to the normal teat-skin colonizing microbiota. However, we cannot exclude the possibility that contaminated milk caused teat apex or skin contamination because, in the current study, specific subtypes were isolated first from the milk and only later from the teat apex. It is not known why some $S$. haemolyticus strains persist on teat apices or in the udder, but the findings of the present study might indicate that certain subtypes are particularly adapted to these mammary tissues whereas others are less so. Possibly, strains with a high capacity to persistently colonize udders exist because of capsule production, as has been described for human strains (Takeuchi et al., 2005).

We conclude that Staphylococcus haemolyticus subtypes occurred on teat apices of infected quarters, suggesting that the agent causing IMI may originate from the teat skin. The repeated isolation of a particular subtype or strain in milk samples of an infected quarter gives a better indication for a persistent IMI than the repeated isolation of a specific species. Hence, when assessing IMI and identifying potential infection sources, CNS identification approaches should aim at subtype or strain characterization rather than merely relying on species-level identification.

\section{ACKNOWLEDGMENTS}

This study was supported by grants from the Research Council of the Vrije Universiteit Brussel (Brussels, Belgium) and the Agency for Innovation by Science and Technology in Flanders (IWT-Vlaanderen, grant no. 60714). The authors thank An Verschaeren, Michiel De Sutter, and Wendie Vanheffen from the Research Group of Industrial Microbiology and Food Biotechnology (IMDO; Brussels, Belgium) and Ann Vanhee from the Institute for Agricultural and Fisheries Research (Melle, Belgium) for the help with the sample processing.

\section{REFERENCES}

Braem, G., S. De Vliegher, K. Supré, F. Haesebrouck, F. Leroy, and

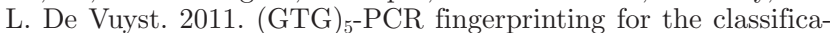
tion and identification of coagulase-negative Staphylococcus species from bovine milk and teat apices: A comparison of type strains and field isolates. Vet. Microbiol. 147:67-74.

Braem, G., S. De Vliegher, B. Verbist, V. Piessens, E. Van Coillie, L. De Vuyst, and F. Leroy. 2013. Unraveling the microbiota of teat apices of clinically healthy lactating dairy cows, with special emphasis on coagulase-negative staphylococci. J. Dairy Sci. 96:1499-1510.

Braem, G., B. Stijlemans, W. Van Haken, S. De Vliegher, L. De Vuyst, and F. Leroy. 2014. Antibacterial activities of coagulase-negative staphylococci from bovine teat apex skin and their inhibitory effect on mastitis-related pathogens. J. Appl. Microbiol. 116:1084-1093.

De Visscher, A., K. Supré, F. Haesebrouck, R. N. Zadoks, V. Piessens, E. Van Coillie, S. Piepers, and S. De Vliegher. 2014. Further evidence for the existence of environmental and host-associated species of coagulase-negative staphylococci in dairy cattle. Vet. Microbiol. 172:466-474.

De Vliegher, S., H. Laevens, L. A. Devriese, G. Opsomer, J. L. M. Leroy, H. W. Barkema, and A. de Kruif. 2003. Prepartum teat apex colonization with Staphylococcus chromogenes in dairy heifers is associated with low somatic cell count in early lactation. Vet. Microbiol. 92:245-252.

Degener, J. E., M. E. O. C. Heck, W. J. Van Leeuwen, C. Heemskerk, A. Crielaard, P. Joosten, and P. Caesar. 1994. Nosocomial infection by Staphylococcus haemolyticus and typing methods for epidemiological study. J. Clin. Microbiol. 32:2260-2265.

Fry, P. R., J. R. Middleton, S. Dufour, J. Perry, D. Scholl, and I. Dohoo. 2014. Association of coagulase-negative staphylococcal species, mammary quarter milk somatic cell count, and persistence of intramammary infection in dairy cattle. J. Dairy Sci. 97:4876-4885.

Hogan, J. S., N. Gonzales, R. J. Harmon, S. C. Nickerson, S. P. Oliver, J. W. Pankey, and B. Soderquist. 1999. Laboratory Handbook on Bovine Mastitis. Rev. ed. National Mastitis Council Inc., Madison, WI.

Noordhoek, G. T., S. A. Scheltinga, P. Caesar, L. M. Schouls, and J. E. Degener. 1997. PCR-based DNA fingerprinting of Staphylococcus haemolyticus to investigate nosocomial infections. Clin. Microbiol. Infect. 3:356-364.

Piessens, V., S. De Vliegher, B. Verbist, G. Braem, A. Van Nuffel, L. De Vuyst, M. Heyndrickx, and E. Van Coillie. 2012. Intra-species diversity and epidemiology varies among coagulase-negative Staphylococcus species causing bovine intramammary infections. Vet. Microbiol. 155:62-71.

Piessens, V., K. Supré, M. Heyndrickx, F. Haesebrouck, S. De Vliegher, and E. Van Coillie. 2010. Validation of amplified fragment length polymorphism genotyping for species identification of bovine associated coagulase-negative staphylococci. J. Microbiol. Methods 80:287-294.

Piessens, V., E. Van Coillie, B. Verbist, K. Supré, G. Braem, A. Van Nuffel, L. De Vuyst, M. Heyndrickx, and S. De Vliegher. 2011. Distribution of coagulase-negative Staphylococcus species from milk and environment of dairy cows differs between herds. J. Dairy Sci. 94:2933-2944. 
Supré, K., F. Haesebrouck, R. N. Zadoks, M. Vaneechoutte, S. Piepers, and S. De Vliegher. 2011. Some coagulase-negative Staphylococcus species affect udder health more than others. J. Dairy Sci. 94:2329-2340.

Takeuchi, F., S. Watanabe, T. Baba, H. Yuzawa, T. Ito, Y. Morimoto, M. Kuroda, L. Cui, M. Takahashi, A. Ankai, S.-i. Baba, S. Fukui, J. C. Lee, and K. Hiramatsu. 2005. Whole-genome sequencing of Staphylococcus haemolyticus uncovers the extreme plasticity of its genome and the evolution of human-colonizing staphylococcal species. J. Bacteriol. 187:7292-7308.

Taponen, S., J. Björkroth, and S. Pyörälä. 2008. Coagulase-negative staphylococci isolated from bovine extramammary sites and intra- mammary infections in a single dairy herd. J. Dairy Res. 75:422429.

Vanderhaeghen, W., S. Piepers, F. Leroy, E. Van Coillie, F. Haesebrouck, and S. De Vliegher. 2014. Invited review: Effect, persistence, and virulence of coagulase-negative Staphylococcus species associated with ruminant udder health. J. Dairy Sci. 97:5275-5293.

Zadoks, R. N., and J. L. Watts. 2009. Species identification of coagulase-negative staphylococci: Genotyping is superior to phenotyping. Vet. Microbiol. 134:20-28.

Zong, Z., C. Peng, and X. Lü. 2011. Diversity of SCCmec elements in methicillin-resistant coagulase-negative staphylococci clinical isolates. PLoS ONE 6:e20191. 